\title{
Does Board Interlock Control High-Tech Performance? Evidence From ASEAN's Growth Countries
}

\author{
Elisa Tjondro $^{1, \mathrm{a}}$, Ning Chang ${ }^{1, \mathrm{~b}}$, Iline Lianata ${ }^{1, \mathrm{c}}$, Veronica Yuliani ${ }^{1, \mathrm{~d}}$, Nathasa Prayitno ${ }^{2, \mathrm{a}}$ \\ ${ }^{1}$ Accounting Departement, Faculty of Business and Economics, Universitas Kristen Petra \\ Jl. Siwalankerto No.121-131, Surabaya, East Java, Indonesia \\ ${ }^{2}$ Graduate Student of MBA Program, National Taiwan of Science and Technology \\ No. 43號, Section 4, Keelung Rd, Da'an District, Taipei City, Taiwan 106 \\ e-mail: ${ }^{1 a^{*}}$ elisatjondro@ petra.ac.id, ${ }^{1 b}$ ningchang201@ gmail.com, ${ }^{1 c}$ ilinelia99@ gmail.com, \\ 1d veronica.lieni08@gmail.com, ${ }^{2 a}$ nathasatata@gmail.com \\ * Corresponding Author
}

\begin{abstract}
The aim of this study is to explain the board interlock association on high-tech firm performance in three growth ASEAN countries. The research samples were 109 high-tech listed manufacturing firms, consisting of 38 Indonesian firms, 37 Malaysian firms, and 34 Thai firms in the 2015-2018 period. The study used panel regression analysis. The research found that corporate governance through interlock directorates is a determinant of high-tech firm performance. The low human capital with high-tech capabilities in ASEAN countries can be overcome by interlocking and facilitating companies to access strategic information. This study also found a positive association between director woman interlock and corporate performance. On the other hand, an independent director who does interlocking actually has a negative effect on company performance. This research is the first research on board interlock in high-tech firms in ASEAN growth countries, Indonesia, Malaysia, and Thailand. There is still limited research involving more than one country, especially developing countries, in studying the interlock board relationship on the company performance. The highlight of this study is to compare the effects of the three interlocks, interlocking directorate, woman interlock, and independent interlock, and their associations on the profitability of high-tech firms. Investors can have an in-depth understanding of the role of the type of interlock that affects the profitability and make the right decision in investing.
\end{abstract}

Keywords ASEAN countries; Firm performance; High-tech firm; Woman interlock; Board interlock; Independent interlock.

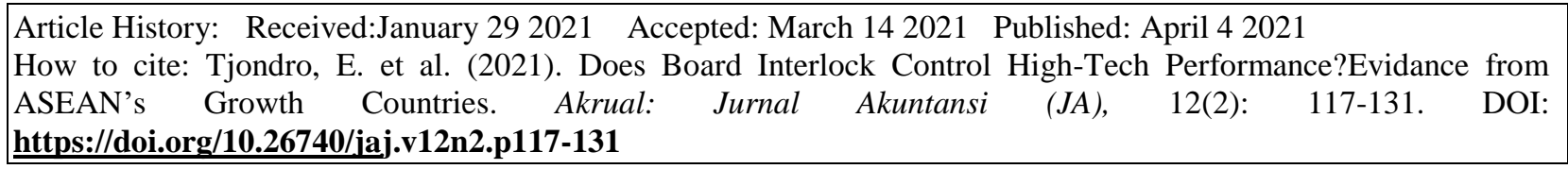

\section{INTRODUCTION}

ASEAN countries which had been originally carried out economic activities based on natural resource products began to shift towards economic activities based on high-tech firm manufacturing (Ho, 2019; Nimtrakoon, 2015; Yatim, Iskandar, \& Nga, 2014). (Saeed, Mukkaram, \& Belghitar, 2019) in their research on the high-tech firm sector in developing countries of India stated that complex innovations and uncertainties arising from the demand 
from customers and technology which are experiencing rapid development are characteristics of high tech firms. In line with (Kwon \& Lee, 2019)stated that high-tech firms that are in a dynamic competitive market environment need to adapt to unexpected demands and offer innovative products that are time-sensitive, to maximize the use of technological innovation. The high growth of the high-tech firm industry is one of the characteristics that distinguish it from other types of industry. In addition to high growth potential, high-tech firms are characterized by inherent uncertainty in the company regarding their firm value, where this value depends on unproven or uncharted future results (Kohers \& Kohers, 2000). As a result of the combination of characteristics they have, risk-taking is needed by high-tech firms (Saeed et al., 2019)

In the corporate governance system, the executive board is a very important position, in which making company policies, making decisions and monitoring the majority of company activities is carried out by the executive board (Ramaswamy, 2019). It is not uncommon for companies to practice interlocking directorate considering the important role played by directors in influencing company performance. Research related to the practice of interlocking directorate has developed rapidly over the last few decades. Lamb \& Roundy (2016) stated that there are opportunities to develop research on interlocking directorate by paying attention to samples of different countries from the general researches. In several studies, the interlocking directorate has the same meaning as the words "dual director", "multiple directorships" and "shared director", which is a condition for someone who holds a position on the executive board is affiliated with a company, sits and also serves on the executive board of other companies that create relationships with companies, shareholders and individuals (Barroso-Castro, VillegasPeriñan, \& Casillas-Bueno, 2016). The relationship that has been formed brings together different directors on one board, thus forming relationships between different companies (Caiazza \& Simoni, 2019).

In developed countries, there are best practices that determine the limit on the number of a board in interlocking. Whereas in developing countries, the number exceeds the existing limits in developed countries (Sarkar \& Sarkar, 2009; Yatim et al., 2014). In developing countries, an executive board can interlock several companies and there are no rules that limit him or her. It is consistent with the findings of (Tan, Kamarudin, Bany-Ariffin, \& Abdul Rahim, 2020), that in Asia Pacific the proportion of councils that interlock in developing countries is greater than in developed. The high number of boards that interlock in developing countries can be caused by the limited number of directors available to companies (Sarkar \& Sarkar, 2009) so that interlocking can be a valuable asset for companies in developing countries (Yatim et al., 2014). In addition, (Arioglu, 2020) stated that if the company wants to survive, it needs to overcome the existing uncertainties. Overcoming uncertainty can be done by practicing interlocking directorate, both general practice of interlocking directorate (Martin, Gözübüyük, \& Becerra, 2013), woman interlock to see from the side of gender diversity (O'Hagan, 2017), and Independent interlock (Liao \& Chen, 2020) to see if the independent director is doing the interlocking.

Most previous studies had conducted research on the board interlock phenomenon (Hernández-lara \& Gonzales-bustos, 2019; Liao \& Chen, 2020; Markoczy, Sun, \& Zhu, 2020; O'Hagan, 2017; Zona, Gomez-Mejia, \& Withers, 2015). The increasing number of studies on the influence of board interlocks on the company has become evidence of the increasing interest in understanding the unique characteristics inherent in interlock boards. (Markoczy et al., 2020), for example, examined the effect of board interlocks on the re-appointment of female directors with 
samples from China. (Liao \& Chen, 2020), conducted research on independent interlock directors on company earnings persistence with samples from China. Research conducted by (Hernández-lara \& Gonzales-bustos, 2019) aimed to study the effect of business relations and social structure of interlocking on innovations with samples from the country of Spain. (O'Hagan, 2017) conducted research on board interlock in terms of gender by finding out the effect of woman interlock on company performance with samples from the USA. (Zona et al., 2015) studied the effect of board interlock on the firms' firm performance and combined the views of agency-resource dependence in explaining their findings with samples from Italy. From several studies related to board interlocks, not too many discussed the effect of more than one type of board interlocks on the firm performance of high-tech firms in developing countries, especially using samples of more than one country. Therefore, this study aims to fill the literature gap by analyzing the effect of board interlock types, namely interlocking directorate, woman interlock, and independent interlock on the firm performance of high-tech firms in developing countries in ASEAN using samples from Indonesia, Malaysia, and Thailand or which is better known as the ASEAN's Growth Triangle.

\section{Resource Dependence theory (RD Theory)}

The literature review process begins by searching for combining the words "Interlock" and "High-tech" by limiting the scope of searches to business, management, and accounting published between 2012 - 2021 and cover only journal articles and conference papers. The searching for word combinations in articles and conference papers was based on abstracts, titles, and keywords. The leading bibliographic databases used in the search for relevant literature are Emerald Insight, Science Direct, and Scopus. The choice of this database is because it has a broad scope of interlocking topics. Researchers found 345 articles based on the keywords "Interlock" when combined with "High-tech" only an article were obtained from the three literature databases. This shows that previous studies on interlocking in high-tech firms are still limited.

The debate about interlocking directorates began way back in 1914, during the emerging debate period (1914-1970), basic concepts and interest in the causes of interlocking directorates emerged which led to the birth of RD theory (Caiazza \& Simoni, 2019), where RD theory formulated by (Pfeffer \& Salancik, 1979). Many studies currently use RD theory in explaining the phenomenon of the interlocking directorate (Hernández-lara \& Gonzales-bustos, 2019; Martin et al., 2013; O'Hagan, 2017; Zona et al., 2015). RD theory describes an organization as an open system in which its performance depends on its ability to get resources from other companies through the reciprocal exchange (Pfeffer \& Salancik, 1979). The executive board is a vital resource for the company because it can equip for a network of the company's external environment (Arioglu, 2020), sharing important knowledge for company managers (K1lıc \& Kuzey, 2016). One of the ways the executive board provides a relationship for the external environment of the company is by the interlocking directorate. (Zona et al., 2015) argued that the relationship formed through an interlocking directorate can provide several benefits such as gaining access to resources, including tangible and intangible resources. Through this interlocking relationship, there is access to a variety of unique information and the ability to learn new organizational practices. Interlocking directorate can affect the performance of an organization by utilizing access to resources from the interlocking relationship for the needs of 
the organization's environment so that the organization gets greater performance benefits (Richardson, 1987).

(Lamb \& Roundy, 2016) and (Martin et al., 2013) stated that resource search is one of the main reasons why board interlocks are formed, there are views from some executives that board interlocks can help companies form connections with other companies, helping executives in securing important resources needed by the company, so as to minimize environmental uncertainty. RD theory explains that a company in response to uncertainty will build a network such as an interlocking directorate to avoid the potential of negative effects of uncertainty in company performance (Martin et al., 2013). Burt (1980) showed that firms tend to interlock with firms in other sectors when they have a dependency relationship where efficient interlocking will increase profitability.

$\mathrm{RD}$ theory recognizes women's participation in the composition of the executive board as an important resource in the board of a company (Adeabah, Gyeke-Dako, \& Andoh, 2018). Their participation can increase profits for company performance. This theory stated that the council as a vital resource can provide external resources by including gender diversity to support the management of environmental uncertainty (Arioglu, 2020). There are still a few female directors who do interlocking in Indonesia, Malaysia, and Thailand, around $8.4 \%$ of the $63.6 \%$ interlocking directorate (table II), because of the patriarchal culture that is still strong in ASEAN countries. It can be said that it is discrimination if the participation of women on a executive board is minimal (Kılıç \& Kuzey, 2016).

Stewardship theories

Stewardship theory stated that this theory provides greater authority and power to the board to act as a steward who is responsible for managing the company. This theory suggests that the council will work hard to achieve the goals of the owners (Boyd, Haynes, \& Zona, 2011). The executive board seeks to achieve shareholder's goals to maximize shareholder's wealth regardless of how much ownership the board has (Subramanian, 2018). In addition, the council is able to unite various interests and is willing to act to protect the owners' long-term interests and welfare (Kallamu \& Saat, 2015).

Essentially, the board can do satisfactory work and become a good steward of assets for the company, so that the executive board who are dominated by inside directors can work to maximize shareholders' wealth (Donaldson, 1990). This theory also stated that inside directors can perform as stewards who have interests that are aligned with shareholders (Davis, Schoorman, \& Donaldson, 1997). Inside directors have more knowledge and information about the company than outside directors or independent directors, where this can support the right decision making (Donaldson \& Davis, 1991). Regarding firm performance, stewardship theory stated that inside directors have a greater influence on board decision making because of their expertise, experience, and knowledge of the company (Kallamu \& Saat, 2015).

Hypotheses

Reducing environmental uncertainty as well as external interdependence is generally carried out by companies that have limited resources and their efforts in managing dependency (Zona et al., 2015) by creating a network of relationships or bringing dependence into the organization is the focus of RD theory. With the interlocking directorate, it can be used as a mechanism to reduce environmental uncertainty in a company (Martin et al., 2013; O'Hagan, 2017). It is in line with the statement of (Ramaswamy, 2019), that interlock acts as a medium of information so that 
habits in other companies will be carried, shared, and implemented in the original company through social relationships that are formed.

When directors occupy several positions on the executive board of other companies, they can create relationships with other companies and influence each other (Caiazza \& Simoni, 2019) the form of access to strategic information resources (Barroso-Castro et al., 2016), minimizing the uncertainty of the business environment, access to unavailable information to the public, combining the strategies and practices of the two companies. When an interlock director is affiliated with another company that has a positive reputation, it will have a positive impact on the performance of the original company (Lamb \& Roundy, 2016). The board relationship that is formed can be a mechanism for exchanging information between companies by bringing together directors who have specific knowledge and sharing that knowledge, thus potentially increasing firm value through additional resources for companies involved in the interlock (Ramaswamy, 2019). Especially in companies that have limited resources, the interlock relationship that is formed will reduce these limitations and improve the performance of the company (Zona et al., 2015). Through this explanation, the proposed hypothesis is:

H1: There is positive influences between the interlocking directorate and the firm performance of the company

Several studies have shown that women have characteristics that make them more valuable than men. First, women tend not to have problems attending board meetings so they are considered more responsible (Arioglu, 2020). Second, in terms of monitoring, women tend to be more diligent when compared to men (Adams \& Ferreira, 2009). Third, gender diversity further increases firm risk-taking (Saeed et al., 2019). Critical resources related to connections (networks) for both customers and competitors, understanding related to the industry, and access to funding can increase the presence of female directors, so that company performance can increase (Reguera-Alvarado, de Fuentes, \& Laffarga, 2015). In addition, the human capital they bring to the board tends to increase the pool of knowledge so that it can create advantages in decision making (Post \& Byron, 2014). Because of these characteristics, (O'Hagan, 2017) stated that companies that fail to recruit female directors have the potential to harm the company's firm performance.

Interlocking can be a way that can help women to gain ease in becoming a member of the executive board (Hernández-lara \& Gonzales-bustos, 2019). Several studies have found a positive influence between women in board positions on the company's firm performance (Arioglu, 2020; Kilıç \& Kuzey, 2016; Post \& Byron, 2014; Reguera-Alvarado et al., 2015), in addition, there is also a finding by (O'Hagan, 2017) that companies have experienced an increase in company performance when the level of participation of female directors in the interlock is high. Because of these findings, the hypothesis put forward for the woman interlock phenomenon is:

$\mathrm{H} 2$. There is a positive influence between woman interlock on the company's firm performance

A director who has added value related to human capital can be appointed to an interlocking position so that one of the motivations for involving the director in interlocking activities is to access the ability, experience, and individual expertise of the director (Lamb \& Roundy, 2016) According to (Hernández-lara \& Gonzales-bustos, 2019), the difference in the influence of the type of director (inside director and outside director) shall constitute a change of the role of 
interlock directors. Outside directors who hold positions on board members and have no special or personal relationship with the company either as employees or former employees are called independent directors (Adams \& Ferreira, 2009). Independent directors have an important role in supervising the board, exerting influence over the choice of company accounting policies and methods (Liao \& Chen, 2020) and monitoring board activity, and controlling decision making by the board (Merendino \& Melville, 2019). Independent interlocks play an important role in bridging the network consisting of interlocks of companies. However, there is literature that claims that independent interlocks can reduce a company performance because independent interlocks networks can form small groups that have the opportunity to collude with each other to thwart shareholders' interests. Unlike the inside director, an independent director who has concurrent positions at several companies at the same time will fail to devote all his abilities to one company (Liao \& Chen, 2020). Based on the stewardship theory, basically, an inside director is an individual who can be trusted and can be called a good steward who will work based on the interests of shareholders (Davis et al., 1997). This theory argued that the majority of boards must consist of inside directors because inside directors have better information and knowledge in making effective decisions than independent directors (Donaldson \& Davis, 1991). Consistent with (Arora \& Sharma, 2016) and (Sanan, Jaisinghani, \& Yadav, 2019) found that there is a negative influence between independent directors and the company's firm performance. Because of this research, the proposed hypothesis is:

H3. There is a negative influence between independent interlocks on the company's firm performance

\section{RESEARCH METHOD}

Sample and data collection

The samples used were high-tech firms in Indonesia, Malaysia, and Thailand. These three countries are three of the five largest developing countries in ASEAN and have the title of the founding countries of ASEAN (Nimtrakoon, 2015). The three countries are growth ASEAN countries that are members of the Indonesia-Malaysia-Thailand Growth Triangle (IMT-GT). This study uses a balanced panel. Samples were companies listed on the Indonesia Stock Exchange (IDX), the Bursa Malaysia (BM), and the Stock Exchange of Thailand (SET), and data were obtained from the annual report and Bloomberg database. (Nimtrakoon, 2015) stated that in the last two decades trade activities between countries in ASEAN have shifted from natural resource-intensive products to high-tech manufactures. The high-tech firm sector classification uses (Cowling, Ughetto, \& Lee, 2018) consists of manufacturing companies engaged in computers, electronic and optical equipment, chemicals and pharmaceuticals, electrical equipment, mechanical machinery, and transportation equipment. The list of companies in Indonesia can be seen on the website www.idx.co.id. Factbook lists all sectors and companies listed in IDX. Annual reports of Indonesian companies were obtained through the IDX website or the company's official website. Annual reports of companies in Malaysia can be downloaded via the website www.bursamalaysia.com. Meanwhile, the list of companies in Thailand was obtained through www.set.or.th. Meanwhile, the companies' financial data were obtained from the Bloomberg database.

The balanced panel data used for this study was from 2015-2018. (Ho, 2019) and (Nimtrakoon, 2015) stated that 2015 is an important moment in the regional economic integration agenda for countries that are members of the Association of Nations. 
Measures

Data on the financial information of companies that originally used their respective currencies was changed based on the year-end exchange rate for the IDR currency in order to facilitate this research.

Dependent Variabel (Firm performance)

Return on Assets (ROA) is an indicator used to measure a company's ability to generate relative profits to the total amount of assets owned by the company which is often used in measuring profitability ratios. ROA provides facilities for comparison with previous studies, where this ratio is commonly used as a reference for company performance index (Zona et al., 2015). ROA can be calculated by dividing net income by the company's total assets. Margin Ratio (Margin) is an indicator that measures the company's ability to generate profits from sales, it can show the company's ability to generate net income from total sales (Nimtrakoon, 2015). The margin ratio can be obtained by dividing net income by total net sales.

Independent Variable

There are countries that implement One-tier boards and there are also those that apply Two-tier boards. In Indonesia, the board structure adheres to the two-tier board, while Malaysia and Thailand adhere to the one-tier board (OECD, 2017). Thus, for this study, the total executive board in Indonesia is obtained by adding up the Executive board and the Board of Commissioners. Interlocking Directorates (interl) can be calculated using the total number of members of the executive board who also serve as members of the executive board of other companies divided by the number of members of the executive board of the company (BarrosoCastro et al., 2016; Hernández-lara \& Gonzales-bustos, 2019). Woman Interlocks (woman) can be measured by the proportion of female directors who interlock the total board members of the company (Hernández-lara \& Gonzales-bustos, 2019). Independent Interlocks (Indep) are used to see the dimensions of the level of independence (Hernández-lara \& Gonzales-bustos, 2019). In which the independent director is an outside director who has been selected for his professional experience and good reputation. Independent interlocks can be measured by the proportion between the number of independent directors who interlock the total board members of the company

\section{Variable Control}

Variable Firm Size (Size) can be measured by the natural logarithm of total assets at the end of the year. Leverage calculated by dividing total debt by total assets. When a company has a high level of leverage, it becomes a risky company and needs to be monitored more so that it can avoid business and financial risks (Yatim et al., 2014). Sales Growth Rate (Growth) can be measured by subtracting last year's sales from last year's sales then dividing it by last year's sales (Nimtrakoon, 2015). Board size (Bsize) measured as the number of members of the executive board, in which the board size is used to control the structure of the board (Arioglu, 2020). Increasing the number of directors can lead to an increase in the talent pool and connections to the outside environment so that it can positively affect the performance.

Empirical model

ROA $_{i, \mathrm{t}}=\mathrm{a}+\beta_{0}$ Interl $_{\mathrm{i}, \mathrm{t}}+\beta_{1}$ woman $_{\mathrm{i}, \mathrm{t}}+\beta_{2}$ Indepi $_{, \mathrm{t}}+\beta_{3}$ Size $_{\mathrm{i}, \mathrm{t}}+\beta_{4} \operatorname{Lev}_{\mathrm{i}, \mathrm{t}}+\beta_{5}$ Growth $_{\mathrm{i}, \mathrm{t}}+\beta_{6}$ Bsize $_{\mathrm{i}, \mathrm{t}}+\varepsilon_{\mathrm{i}, \mathrm{t}}$ 
$\operatorname{Margin}_{i, t}=a+\beta_{0} \operatorname{Interl}_{i, t}+\beta_{1}$ woman $_{i, t}+\beta_{2} \operatorname{Indep}_{i, t}+\beta_{3} \operatorname{Size}_{i, t}+\beta_{4} \operatorname{Lev}_{i, t}+\beta_{5} \operatorname{Growth}_{i, t}+\beta_{6}$ Bsize $_{i, t}+\varepsilon \varepsilon_{i, t}$

\section{RESULTS AND DISCUSSION}

Table 1 shows a summary of the samples observed in this study. Initially, 171 companies were included in the high-tech firm sector in Indonesia, Malaysia, and Thailand. However, during the process of searching for data, there were 52 companies that did not have complete annual reports from 2015-2018. Several companies excluded from the sample because of several criteria as in table 1 . Thus, in the end, there are 109 companies with 436 observation that can be used as the population in this study.

Table 1. Sampling criteria

\begin{tabular}{lcccc}
\hline Sampling criteria & Full sample & Indonesia & Malaysia & Thailand \\
\hline High-tech firm & 171 & 49 & 55 & 67 \\
$\begin{array}{l}\text { Companies which annual reports are } \\
\text { incomplete }\end{array}$ & $(52)$ & $(9)$ & $(18)$ & $(25)$ \\
Companies which annual reports do not use & & & & \\
English & $(10)$ & $(2)$ & 0 & $(8)$ \\
Total company & 109 & 38 & 37 & 34 \\
Total period & 4 & 4 & 4 & 4 \\
The total observation & 436 & 152 & 148 & 136 \\
\hline
\end{tabular}

Table 2 shows that an average of $63.6 \%$ of the companies in the study sample conducted an interlocking directorate with a standard deviation of $29.3 \%$. The maximum value of 1 indicate there are companies that all members of the board perform interlocking directorate in other companies. For the woman interlock, the average value obtained is small, namely $8.4 \%$. There is a maximum value of $50 \%$ in a company, which means that half of the members of the executive board who perform interlocking directorate are women. As for the Independent Interlock, the average value obtained is $25.1 \%$, having a maximum value of $75 \%$ in a company where members of the executive board who perform the interlocking directorate are members of independent directors. For the interlocking directorate, the woman interlock and the independent interlock both have a minimum value of 0 . This means that there are companies where the executive board does not perform the interlocking directorates, woman interlocks, or independent interlocks at all.

Table 2. Descriptive Statistics

\begin{tabular}{lccccc}
\hline Variable & Mean & Median & Min & Max & SD \\
\hline ROA & 0.048 & 0.045 & -0.308 & 0.921 & 0.08 \\
Margin & 0.052 & 0.054 & -5.778 & 1.901 & 0.37 \\
Interl & 0.636 & 0.7 & 0 & 1 & 0.293 \\
Woman & 0.084 & 0 & 0 & 0.5 & 0.11 \\
Indep & 0.251 & 0.25 & 0 & 0.75 & 0.187 \\
Size & 28.407 & 28.147 & 25.749 & 33.474 & 1.592 \\
Lev & 0.196 & 0.166 & 0 & 0.811 & 0.163 \\
Growth & 0.067 & 0.048 & -0.888 & 5.415 & 0.404 \\
Bsize & 8.736 & 8 & 4 & 26 & 3.112 \\
\hline
\end{tabular}


The classic assumption test used in this study consists of a heteroscedasticity test and a multicollinearity test. When the heteroscedasticity test results show a $p$-value less than 0.05 , it means that the model used has heteroscedasticity. Apart from the heteroscedasticity test, another classic assumption test that was carried out was the multicollinearity test. (Wooldridge, 2013) stated that in determining multicollinearity, sometimes the value of 10 is selected in determining the cut off value for VIF. The VIF value of all variables in this study has the highest value for VIF is 2.471 which is owned by the Interl variable (interlocking directorates). It can be concluded there is no problem of multicollinearity in this model.

In assessing panel data, determining model estimates is important. Table 3 shows the results of the panel model test where based on the Hausman test the random effect model is more suitable for ROA while the Fixed effect model is more suitable for Margin ratio. However, in the Fixed effect model, the assumption of heteroscedasticity must be fulfilled and this is not fulfilled in this research model. This study has a greater between effects variation than the within effects variation, so it is more appropriate to use random effect model. Fixed effect models make heteroscedasticity assumptions while random effect models will allow heterogeneity modeling between units.

Table 3. Summary of panel effect tests

\begin{tabular}{lcl}
\hline Dependent variables & ROA (p-value) & Margin $(\mathrm{p}$-value $)$ \\
\hline $\begin{array}{l}\text { The Fixed effect estimator } \\
\text { Result }\end{array}$ & 4,43872 e-029 & 8,76502 e-015 \\
Random effect estimator & Fixed & Fixed \\
Breusch-Pagan test statistic & 8,71696 e-035 & 3,52442 e-013 \\
Result & Random & Random \\
Hausman test statistic & 0.096698 & 1,16906 e-008 \\
Result & Random & Fixed \\
\hline
\end{tabular}

Table 4 shows the final model in the form of the random effect model. H1 states that there is a positive association between the interlock directorate and the company's firm performance. The results of the analysis in table 4 show that the interlocking directorate has a significant positive relationship with company performance, it is concluded that $\mathrm{H} 1$ is accepted. This finding has similarities with the findings of (Barroso-Castro et al., 2016; Martin et al., 2013; Zona et al., 2015), in which their research found that the interlocking directorate has a positive impact on a company's firm performance.

$\mathrm{H} 2$ states that woman interlock has a positive association when it comes to the company's firm performance. The results of the analysis in table 4 show that the woman interlock has a positive association with ROA and Margin, it is concluded that the proposed $\mathrm{H} 2$ is acceptable. The results of these findings are in line with research conducted by (O'Hagan, 2017) which found that woman interlock has a positive effect on the company's firm performance.

$\mathrm{H} 3$ states that the existence of independent interlocks has a negative effect on the company's firm performance. Table 4 shows the results that are consistent with the hypotheses formulated in this study, thus $\mathrm{H} 3$ can be accepted. The results of this study are consistent with the findings of previous studies, among others (Arora \& Sharma, 2016; Sanan et al., 2019) which found that board independence has a negative effect on the company's firm performance. 
Table 4. Final regression model for board interlock and firm performance with Random Effect

\begin{tabular}{|c|c|c|c|c|c|c|}
\hline \multirow{2}{*}{ Variable } & \multicolumn{3}{|c|}{$\mathrm{ROA}$} & \multicolumn{3}{|c|}{ Margin } \\
\hline & Coeff & Std. error & $p$-value & Coeff & Std. error & $p$-value \\
\hline Const & 0.0099 & 0.108 & 0.927 & -0.243 & 0.4275 & 0.570 \\
\hline Interl & 0.065 & 0.024 & $0,007 * * *$ & 0.228 & 0.1067 & $0,033^{* *}$ \\
\hline Woman & 0.084 & 0.049 & $0,085^{*}$ & 0.181 & 0.2126 & 0.395 \\
\hline Indep & $-0,088$ & 0.036 & $0,015 * *$ & -0.151 & 0.1581 & 0.341 \\
\hline Size & 0.0008 & 0.004 & 0.847 & 0.009 & 0.0165 & 0.606 \\
\hline Lev & $-0,097$ & 0.030 & $0,001 * * *$ & -0.523 & 0.1282 & $0.000 * * *$ \\
\hline Growth & 0.027 & 0.007 & $0.000 * * *$ & 0.107 & 0.0378 & $0,005 * * *$ \\
\hline Bsize & 0.0007 & 0.002 & 0.719 & 0.003 & 0.0084 & 0.725 \\
\hline Adjusted $\mathrm{R}^{2}$ & \multicolumn{3}{|c|}{0.142926} & \multicolumn{3}{|c|}{0.119254} \\
\hline$p$-value $(\mathrm{F})$ & \multicolumn{3}{|c|}{1,44906 e-006 } & \multicolumn{3}{|c|}{$1,30262 \mathrm{e}-005$} \\
\hline
\end{tabular}

First, the results of our research related to the corporate governance mechanism through the interlocking directorate have a positive and significant effect on the company's firm performance. This indicates that in developing countries in ASEAN, the practice of interlocking directorate can improve the firm performance of companies. Tan et al. (2020) who conducted cross-country research, that the proportion of interlocking directorates in developing countries is more than in developed countries in the Asia Pacific region. This finding also implies that in developing countries in ASEAN there are limited people who have the expertise for companies (Sarkar \& Sarkar, 2009), so that the presence of an interlocking directorate on the executive board can be a method of addressing the limitations of experts, given that high tech firms are companies that have complex innovation characteristics (Saeed et al., 2019), are in a dynamic competitive environment (Kwon \& Lee, 2019). Martin et al. (2013) found that there is a strong positive effect between the company's firm performance and the interlocking directorate, especially when the company's environmental uncertainty is very high. Thus according to the RD theory, when there are uncertainties or limitations, the company will build a relationship with companies that have the resources so that it can reduce these problems (Caiazza \& Simoni, 2019). The interlocking directorate practice carried out by the company will increase and restructure resource dependence so that it can improve company performance, this can happen when the original company which has limited resources interlocking directorate with companies that have higher resources (Zona et al., 2015). The interlocking relationship that is formed can facilitate access to strategic information (Barroso-Castro et al., 2016), resources that cannot be created by internal companies (O'Hagan, 2017), a forum for information exchange between companies (O'Hagan, 2017; Ramaswamy, 2019). Thus we agree with the opinion of Yatim et al. (2014) that the interlocking directorate can be a valuable corporate asset in developing countries.

We found that the participation of female directors in the woman interlock shows a positive and significant effect on firm performance in high-tech firms in Indonesia, Malaysia, and Thailand. This finding implies that woman interlock is one of the important practices in the executive board that can support the firm performance of high-tech firms in developing countries in ASEAN. When viewed from the characteristics of high-tech firms, namely having complex innovation (Saeed et al., 2019), fast growth, and the inherent uncertainty in the company (Kohers 
\& Kohers, 2000). Women who occupy board positions in developing countries, especially in the high-tech firm sector, tend to have risk-taker characteristics (Saeed et al., 2019) so that the presence of women on the executive board can increase a company's risk-taking. (Wiley \& Monllor-Tormos, 2018) stated that the strong pressure arising from competition causes high-tech firms need to take investment strategies that have a high risk. There has been an increase in the quality of decision making with the participation of women on the board, from the view of RD theory (Adeabah et al., 2018). Women can provide added value by sharing ideas and new perspectives on the board (Adams \& Ferreira, 2009), building a positive image also increasing the competitive advantage (Kılıç \& Kuzey, 2016). In addition, female directors who participate in the Interlock can be a potential in a unique knowledge transfer mechanism, reducing uncertainty in the environment outside the company, so as to increase profitability for the company is greater than male directors (O'Hagan, 2017). This finding is supported by Post \& Byron (2014) who found that female directors have a cognitive framework that positively influences decision-making, including the experiences, knowledge, and values that female directors bring to the board where all three will add important information that is considered in decision making, thus increasing the ability of the company to create profits from investments and assets owned by the company.

An important finding in this study is that the number of female directors who interlocked in Indonesia, Malaysia, and Thailand was very minimal, only around $8.4 \%$ of $63.6 \%$ of the total number of directors who interlocked. This is very much influenced by the patriarchal culture in ASEAN countries which is still strong. The view that women have a lower long-term commitment to companies than men, women who are more closely related to family relationships, can hinder women's career development and lead to fewer women being selected in important positions in some industries (Arena et al., 2015).

The presence of independent interlock directors has a significant negative effect on the firm performance of high-tech companies in ASEAN. When the number of independent interlocks on the executive board increases, the company's firm performance will be lower. There are several reasons for this result. First, it is consistent with the stewardship theory, wherein principle the inside director can act as a good steward who can support and protect the interests of shareholders (Davis et al., 1997) compared to independent directors. Second, if a problem occurs, perhaps the independent director can act faster than the inside director, but they may make mistakes if their judgment is not influenced by the information held by the inside director. On the other hand, inside directors have better expertise, knowledge, and experience about the company when compared to independent directors, so they have a greater influence in board decision making (Kallamu \& Saat, 2015). Third, the factor of independence of outside directors in ASEAN countries is often questioned. In developing countries, it is common to find the same board serving as an independent interlock (outside director) simultaneously at several companies. This can occur due to the limited number of independent directors who have good competence in developing countries (Arora \& Sharma (2016), especially in high-tech firms where there are few human capital with high-tech capabilities.

\section{CONCLUSION}

The purpose of this study is to explain the board interlock association with high-tech firm performance in three growth ASEAN countries (Indonesia, Malaysia, and Thailand). This study found that the number of female directors who interlocked in Indonesia, Malaysia, and Thailand 
was very small, around $8.4 \%$ of $63.6 \%$ of the total number of directors who interlocked. Another finding is that an increase in the number of female directors who perform interlocking is positively related to the profitability of high-tech firms. There is an increase in the quality of decision making with the participation of women on the board, from the point of view of RD theory (Adeabah et al., 2018). In addition, this study found that the presence of an independent interlock director has a significant negative effect on the firm performance of high-tech companies in ASEAN. When the number of independent interlocks on the executive board increases, the company's firm performance will be lower. The test results did not change after performing the robustness test.

This study has some limitations. This study only focuses on internal mechanism corporate governance as independent variables, especially board interlocking, woman interlocking, and independent interlocking. In addition, the samples of ASEAN countries used are only three countries, namely Indonesia, Malaysia, Thailand, so it has weaknesses in generalizing the results for the ASEAN region. Future research can try to research other industrial sectors and update the observation period to obtain new evidence regarding the relationship between board interlocking and company performance.

\section{REFERENCES}

Adams, R. B., \& Ferreira, D. (2009). Women in the boardroom and their impact on governance and performance. Journal of Financial Economics, 94(2), 291-309. https://doi.org/10.1016/j.jfineco.2008.10.007

Adeabah, D., Gyeke-Dako, A., \& Andoh, C. (2018). Board gender diversity, corporate governance and bank efficiency in Ghana: a two stage data envelope analysis (DEA) approach. Corporate Governance (Bingley), 19(2), 299-320. https://doi.org/10.1108/CG08-2017-0171

Arena, C., Cirillo, A., Mussolino, D., Pulcinelli, I., Saggese, S., \& Sarto, F. (2015). Women on board: Evidence from a masculine industry. Corporate Governance (Bingley), 15(3), 339356. https://doi.org/10.1108/CG-02-2014-0015

Arioglu, E. (2020). Female board members: the effect of director affiliation. Gender in Management, 35(2), 225-254. https://doi.org/10.1108/GM-05-2019-0080

Arora, A., \& Sharma, C. (2016). Corporate governance and firm performance in developing countries: evidence from India. Corporate Governance: The International Journal of Business in Society, 16(2), 420-436. https://doi.org/10.1108/CG-01-2016-0018

Barroso-Castro, C., Villegas-Periñan, M. del M., \& Casillas-Bueno, J. C. (2016). How boards' internal and external social capital interact to affect firm performance. Strategic Organization, 14(1), 6-31. https://doi.org/10.1177/1476127015604799

Boyd, B. K., Haynes, K. T., \& Zona, F. (2011). Dimensions of CEO-Board Relations. Journal of Management Studies, 48(8), 1892-1923. https://doi.org/10.1111/j.1467-6486.2010.00943.x

Burt, R. S. (1980). Cooptive Corporate Actor Networks: A Reconsideration of Interlocking Directorates Involving American Manufacturing. Administrative Science Quarterly, 25(4), 557-581. https://doi.org/10.2307/2392281

Caiazza, R., \& Simoni, M. (2019). Directorate ties: a bibliometric analysis. Management 
Decision, 57(10), 2837-2851. https://doi.org/10.1108/MD-01-2018-0085

Cowling, M., Ughetto, E., \& Lee, N. (2018). The innovation debt penalty: Cost of debt, loan default, and the effects of a public loan guarantee on high-tech firms. Technological Forecasting and Social Change, 127(May 2016), 166-176. https://doi.org/10.1016/j.techfore.2017.06.016

Davis, J. H., Schoorman, F. D., \& Donaldson, L. (1997). Toward a stewardship theory of management. Academy of Management Review, 22(1), 20-47.

Donaldson, L. (1990). The Ethereal Hand : Organizational Economics and Management Theory. Academy of Managament, 15(3), 369-381.

Donaldson, L., \& Davis, J. H. (1991). Stewardship Theory or Agency Theory: CEO governance and shareholder returns. Australian Journal of Management, 16(1), 49-64.

Hernández-lara, A. B., \& Gonzales-bustos, J. P. (2019). The impact of interlocking directorates on innovation: The effects of business and social ties. Management Decision, 57(10), 2799-2815. https://doi.org/10.1108/MD-11-2017-1186

Ho, S. W. H. (2019). Preparedness for ASEAN Economic Community (AEC): a case study of Malaysian SME manufacturing sector. Journal of Asia Business Studies, 13(3), 384-411. https://doi.org/10.1108/JABS-01-2017-0018

Kallamu, B. S., \& Saat, N. A. M. (2015). Audit committee attributes and firm performance: evidence from Malaysian finance companies. Asian Review of Accounting, 23(3), 206-231. https://doi.org/10.1108/ARA-11-2013-0076

Kılıç, M., \& Kuzey, C. (2016). The effect of board gender diversity on firm performance: evidence from Turkey. Gender in Management, 31(7), 434-455. https://doi.org/10.1108/GM-10-2015-0088

Kohers, N., \& Kohers, T. (2000). The Value Creation Potential of High-Tech Mergers. Financial Analysts Journal, 56(3), 40-50. https://doi.org/10.2469/faj.v56.n3.2359

Kwon, H. B., \& Lee, J. (2019). Exploring the differential impact of environmental sustainability, operational efficiency, and corporate reputation on market valuation in high-tech-oriented firms. International Journal of Production Economics, 211(June 2018), 1-14. https://doi.org/10.1016/j.ijpe.2019.01.034

Lamb, N. H., \& Roundy, P. (2016). The "ties that bind" board interlocks research: a systematic review. Management Research Review, 39(11), 1516-1542. https://doi.org/10.1108/MRR02-2015-0027

Liao, F. N., \& Chen, F. W. (2020). Independent director interlocks: effects and boundary on the earnings persistence of the firm. Economic Research-Ekonomska Istrazivanja , O(0), 1-27. https://doi.org/10.1080/1331677X.2020.1788965

Markoczy, L., Sun, S. L., \& Zhu, J. (2020). Few women on boards: What's identity got to do with it? Journal of Business Ethics, 165(2), 311-327. https://doi.org/10.1007/s10551-01904104-z

Martin, G., Gözübüyük, R., \& Becerra, M. (2013). Interlock and firm performance : The role of 
uncertainty in the directorate interlock-performance relationship. Strategic Management Journal, (September 2013), 1-43. https://doi.org/10.1002/smj

Merendino, A., \& Melville, R. (2019). The board of directors and fi rm performance : empirical evidence from listed companies. Corporate Governance, 19(3), 508-551. https://doi.org/10.1108/CG-06-2018-0211

Nimtrakoon, S. (2015). The relationship between intellectual capital, firms' market value and financial performance: Empirical evidence from the ASEAN. Journal of Intellectual Capital, 16(3), 587-618. https://doi.org/10.1108/JIC-09-2014-0104

O'Hagan, S. B. (2017). An exploration of gender, interlocking directorates, and corporate performance. International Journal of Gender and Entrepreneurship, 9(3), 269-282. https://doi.org/10.1108/IJGE-09-2016-0032

OECD. (2017). OECD Survey of Corporate Governance Frameworks in Asia. 1-45.

Pfeffer, J., \& Salancik, G. R. (1979). The External Control of Organizations. A Resource Dependence Perspective. The Economic Journal, 89(356), 969. https://doi.org/10.2307/2231527

Post, C., \& Byron, K. (2014). Women on boards and firm financial performance: A metaanalysis. Academy of Management Journal, 17(2), 491-549. https://doi.org/10.1007/s10997-011-9186-1

Ramaswamy, V. (2019). Director interlocks and cross-cultural impact on strategies affecting shareholder-creditor conflicts: A conceptual analysis. Management Decision, 57(10), 26932713. https://doi.org/10.1108/MD-10-2017-0956

Reguera-Alvarado, N., de Fuentes, P., \& Laffarga, J. (2015). Does Board Gender Diversity Influence Financial Performance? Evidence from Spain. Journal of Business Ethics, 141(2), 337-350. https://doi.org/10.1007/s10551-015-2735-9

Richardson, R. J. (1987). Directorship interlocks and corporate profitability. Administrative Science Quarterly, 32(3), 367-368. https://doi.org/10.2307/2392910

Saeed, A., Mukkaram, S. S., \& Belghitar, Y. (2019). Read between the lines: Board gender diversity, family ownership, and risk-taking in Indian high-tech firms. International Journal of Finance and Economics, (October 2018), 1-23. https://doi.org/10.1002/ijfe.1784

Sanan, N. K., Jaisinghani, D., \& Yadav, S. (2019). Corporate governance, firm performance, and business group affiliation: evidence from India. Management Decision. https://doi.org/10.1108/MD-03-2019-0376

Sarkar, J., \& Sarkar, S. (2009). Multiple board appointments and firm performance in emerging economies: Evidence from India. Pacific Basin Finance Journal, 17(2), 271-293. https://doi.org/10.1016/j.pacfin.2008.02.002

Subramanian, S. (2018). Stewardship Theory of Corporate Governance and Value System: The Case of a Family-owned Business Group in India. Indian Journal of Corporate Governance, 11(1), 88-102. https://doi.org/10.1177/0974686218776026

Tan, K. M., Kamarudin, F., Bany-Ariffin, A. N., \& Abdul Rahim, N. (2020). Moderation of directors' education on board busyness-firm efficiency. Management Decision, 58(7), 
1397-1423. https://doi.org/10.1108/MD-09-2017-0905

Wiley, C., \& Monllor-Tormos, M. (2018). Board Gender Diversity in the STEM\&F Sectors: The Critical Mass Required to Drive Firm Performance. Journal of Leadership \& Organizational Studies, 25(3), 290-308. https://doi.org/10.1177/1548051817750535

Wooldridge, J. M. (2013). Introductory econometrics a modern approach 5th edition (5th ed.). Mason: South-Western. https://doi.org/10.4324/9781351140768-8

Yatim, P., Iskandar, T. M., \& Nga, E. (2014). Board attributes and foreign shareholdings in Malaysian listed firms. Journal of Management and Governance, 20(1), 147-178. https://doi.org/10.1007/s10997-014-9301-1

Zona, F., Gomez-Mejia, L. R., \& Withers, M. C. (2015). Board Interlocks and Firm Performance: Toward a Combined Agency-Resource Dependence Perspective. Journal of Management, 44(2), 589-618. https://doi.org/10.1177/0149206315579512 